\title{
Comparison of the Clinical Characteristics and Mortality of Adults Infected with Human Coronaviruses 229E and OC43
}

Won-II Choi ( $\square$ choi_wi@hanmail.net)

Keimyung University Dongsan Medical Center https://orcid.org/0000-0001-7705-0098

Choong Won Lee

Andong Sungso Hospital

\section{Research article}

Keywords: Human coronavirus infections, respiratory virus infections, human coronavirus $229 \mathrm{E}$, human coronavirus $\mathrm{OC} 43$

Posted Date: September 3rd, 2020

DOI: https://doi.org/10.21203/rs.2.15496/v2

License: (c) (1) This work is licensed under a Creative Commons Attribution 4.0 International License.

Read Full License

Version of Record: A version of this preprint was published at Scientific Reports on February 24th, 2021. See the published version at https://doi.org/10.1038/s41598-021-83987-3. 
The authors have withdrawn this preprint from Research Square 